\title{
Dinoflagellate cyst stratigraphy of the Lower Cretaceous Jydegård Formation, Bornholm, Denmark
}

\author{
Stefan Piasecki
}

\begin{abstract}
Piasecki, S.: Dinoflagellate stratigraphy of the Lower Cretaceous Jydegård Formation, Bornholm, Denmark. Bull. geol. Soc. Denmark, vol. 32, pp 145-161, Copenhagen, september, 4th, 1984. https://doi.org/10.37570/bgsd-1983-32-11

Two Danish Geological Survey boreholes in the Lower Cretaceous fine-grained Rødbjerg Member (Jydegård Formation) in the Nyker fault-block on Bornholm have yielded dinoflagellate cysts which can date the sequence as latest Ryazanian to earliest Valanginian. Two dinoflagellate zones are identified, a lower Gochteodinium villosa Zone and an upper Pseudoceratium pelliferum Zone. The age assignment is in agreement with previous ostracod datings. One new dinoflagellate cyst species, Mendicodinium rugarum, is erected and one monospecific genus and the species is emended, Lagenorhytis- L. delicatula. The morphology and distribution of Sentusidinium pelionense, Cantulodinium speciosum and aff. Chlamy-dophorella nyei are discussed.
\end{abstract}

Stefan Piasecki, The Geological Survey of Greenland, Øster Voldgade 10, DK-1350 Copenhagen K, Denmark, January 27th, 1984.

\section{Introduction}

The island Bornholm is a fault-block associated with the Fenno-Scandian Border Zone (fig. 1) and, therefore, structually similar to the basement horsts of southern Sweden. The Precambrian crystalline basement of Bornholm represents more than $50 \%$ of surface exposure, but younger sediments on the southern part of the island are preserved on top of the basement. The fault-block itself is dissected into minor blocks which expose a complex mosaic of Lower Palaeozoic and Mesozoic sediments. The Triassic to Jurassic sediments were mainly deposited in terrestrial environments but the Cretaceous sediments show a generally increasing marine influence upwards.

The Lower Cretaceous Nyker Group (Gravesen, Rolle \& Surlyk 1982) comprises three formations, the Rabekke, Robbedale and Jydegård Formations all of which were defined by Gry $(1956,1960)$. These formations are generally considered to be of earliest Cretaceous age but the Rabekke Formation may be of latest Jurassic age. A detailed resume is found in Gravesen, Rolle \& Surlyk (1982) together with a complete reference list.
Gravesen et al. (1982) subdivided the Jydegård Formation into the fine-grained Rødbjerg Member and the coarse-grained Tornh $ø j$ Member. The two members were considered lateral equivalents and the present investigation supports this conclusion.

Noe-Nygaard \& Surlyk (in prep.) interpret the

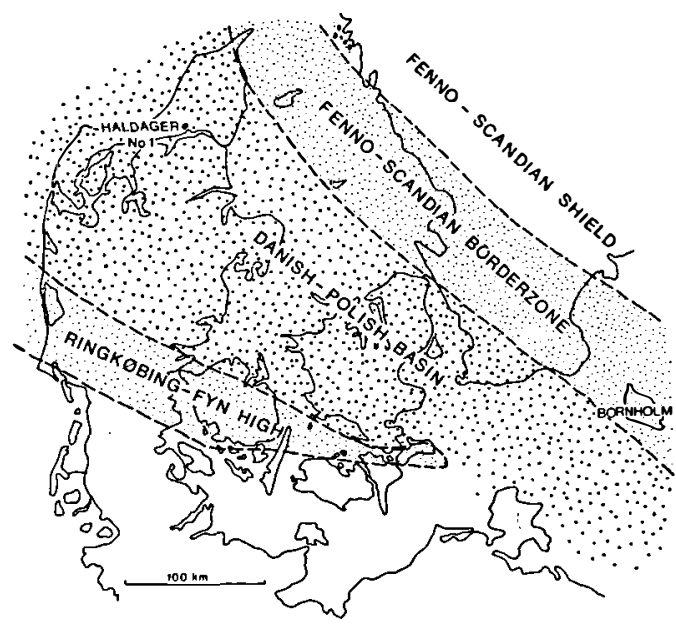

Fig. 1. Sketch-map of the Danish - Polish Basin. The positions of the Haldager no. 1 well and the island Bornholm are marked. 
Rødbjerg Member as a lagoonal mud with distal washover fans. The contemporaneous Tornhøj Member is interpreted as a back-barrier sand with subordinate marginal lagoonal mud followed by a coarse-grained meander belt in the upper part. In some levels, the fine-grained beds of the Tornh $\varnothing j$ Member contain monotypic dinoflagellate cyst assemblage (Piasecki in prep.) which show strong similarity to the assemblages from the lower part of Rødbjerg Member. The present stratigraphical investigation is restricted to the fine-grained Rødbjerg Member of the Nyker fault-block (fig. 2) which is not exposed, the analyses being of core-samples from two boreholes ( 244165 and 244226 ) made by the Geological Survey of Denmark (Gry 1956). Christensen $(1963,1974)$ stratigraphically examined these boreholes for ostracods and correlated his zonation with zonations in northern Germany.

\section{Methods}

The samples were prepared using standard palynological techniques. The silica was removed by hydrofluoric and hydrochloric acid and the

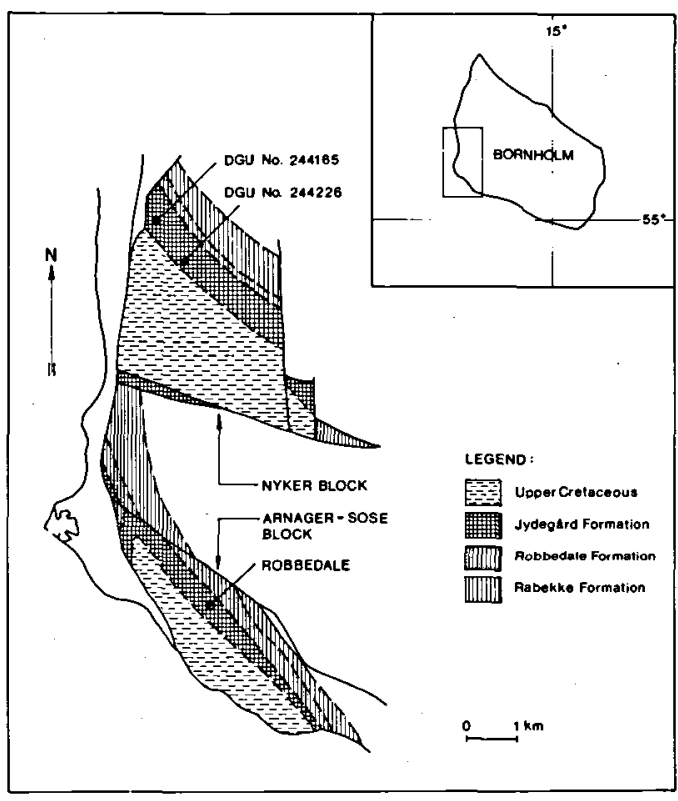

Fig. 2. Geological map of the SW-corner of Bornholm with the distribution of the Nyker Group. The positions of the investigated boreholes and the important outcrop locality of the Jydegård Formation are marked (Modified from Gry 1960, 1969). organic residue was briefly oxidized by fuming nitric acid and then washed with a low concentration of potassium hydroxide. Some samples contained a very high concentration of unstructured, liptinitic material which was resistent to oxidation. This material appeared to possess a low specific gravity compared to the rest of the organic residue. By centrifuging the residue in a liquid of a specific gravity of 1.4 , the organic residue separated into one floating fraction of the unstructured material and a bottom residue fraction including dinoflagellate cysts.

Type specimens and figured specimens are stored in the Geological Museum of the University of Copenhagen and are marked with a MGUH-number.

\section{Systematics}

The systematic proposals of Lentin \& Williams (1981) and of Davey (1982) are followed in this paper. The morphological terminology of the descriptions are based on suggestions by Evitt (1967) and Evitt, Lentin, Millioud, Stover \& Williams (1977).

The brackish environment of the Jydegård Formation (Noe-Nygaard \& Surlyk in prep., Piasecki in prep.) has adversely affected the morphology of several dinoflagellate cysts species, especially the chorate cysts. Therefore identification to species level has not always been possible. It is suspected that several of the non-identified species are morphological variations of well known marine species. The following descriptions are arranged alphabetically.

Genus Cantulodinium Alberti, 1961.

Cantulodinium speciosum, Alberti, 1961. Plate 1, figs 9-13; text fig. 3.

1961 Cantulodinium speciosa Alberti, p. 23, Pl. 3, figs 20-23; PI. 12, fig. 3.

1978 Cantulodinium speciosum Alberti in Stover \& Evitt, p. 97-98.

1982 Cantulodinium speciosum Alberti in Davey, p. 25 Pl. 4, fig. 11. 

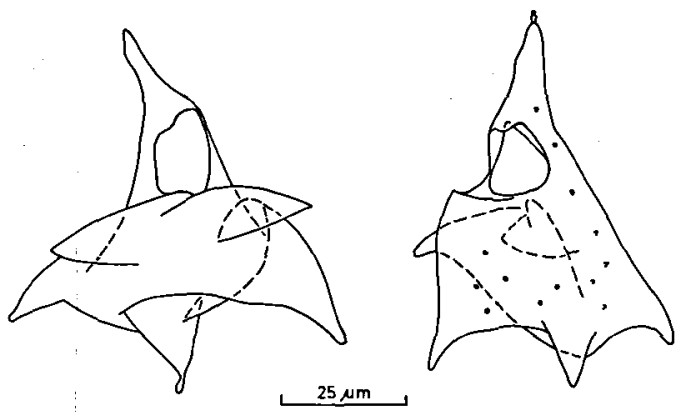

Fig. 3. Camera lucida drawings of Cantulodinium speciosum to show the archaeopyle type and the effect of compression to the hypocyst and the "post-cingular" horns.

Remarks: Since the original description of this species by Alberti (1961) no reports of significant numbers of $C$. speciosum have been published. This reflects that either the species is resticted geographically or that brackish/freshwater sediments (e.g. Purbeck-Wealden) have been neglected.

On the other hand, the reports of Stover \& Evitt (1978) and Davey (1982) indicate that the species does occur in marine sediments, although it may be transported from elsewhere in the basin.

Description: The outline of the cyst is bottleshaped. The epicyst extends into a tappering apical horn which is pointed or rounded at the apex. An apicular structure, a small massive elongation of the apex, is common and is very similar to the clavate sculptural elements which may occur on the surface of the cyst. The cyst increases in width from apex towards antapex, and the maximum width of the body occurs on the posterior part of the hypocyst which has a flat or concave antapical region. The width of the hypocyst is increased by 5 strongly tappering horns which radiate from the hypocyst. On well preserved specimens the 5 horns are of approximately equal size, but the compression of the cyst generally blurs the impression of the size and position of the horns. On the basis of their distribution and number, the horns may be interpreted as equivalent to the plates of the postcingular plate-series of a peridinoid tabulation pattern.

The wall is one-layered, the autophragm, and has no internal structures. The thickness is approximately $1 \mu \mathrm{m}$. The surface of the autophragm may be smooth, but sculptural elements of vary- ing shape and density are commonly present. The entire surface may be densely covered by fine granulae or more scattered coarser granulae alternating with clavulae and short irregular, massive spines. The hypocyst is generally more intensely sculptured than the epicyst and, in addition, the density of sculpturing may vary over the cyst surface. Sculpture density differs from one specimen to another.

The archaeopyle is intercalary of type $2 \mathrm{I}$. The operculum is compound and equivalent to the intercalary paraplates $2 \mathrm{a}$ and $3 \mathrm{a}$.

The paratabulation is not indicated by any structures except for the archaeopyle and possibly the position of the horns on the hypocyst. The shape and position of the archaeopyle and the two opercular pieces indicate equivalence to paraplate $2 \mathrm{a}$ and $3 \mathrm{a}$ of the anterior intercalary plate series in a peridinoid tabulation system. The number and the position of the horns on the hypocyst indicate an equivalence to the 5 postcingular plates in the peridinoid tabulation pattern. A paratabulation formula cannot be established but a peridinoid affinity is suggested.

Discussion: C. speciosa from the Jydegård Formation is very similar to the type-material from northern Germany. The main differences concern the number, position and size-variation of the postcingular horns. Alberti (1961) described variation in the number of horns from 3 to 5 , but in the present material all specimens have 5 postcingular horns. Further, the extreme variation in size and position (location) of the horns described by Alberti (e.g. see pl. 12, fig. 3) is not present in the Bornholm material. The size of a specific horn is very difficult to estimate and the compression of the cysts increases this problem. However, size-variation appears to be small. Differences in the position of the horns also appear to relate to compression.

The holotype of $C$. speciosa (Alberti 1961) and the specimen figured by Davey (1982) have broad and rounded hypocysts in contrast to most of the specimens from the Jydegård Formation. This is considered to be intra-specific variation.

Dimensions: 25 well preserved specimens were measured. The total length of the cysts varies from 52 to $80 \mu \mathrm{m}$, average $67 \mu \mathrm{m}$. The width of the main body varies from 28 to $49 \mu \mathrm{m}$, average $37 \mu \mathrm{m}$, and the total width including the horns varies from 46 to $70 \mu \mathrm{m}$, average $57 \mu \mathrm{m}$. 


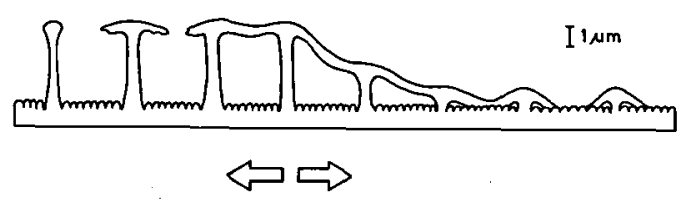

Fig. 4. Sketch of the aff. Chlamydophorella nyei wall structures and the recognised variation trends. The structure above the arrows is supposed to be the "normal" wall structure.

\section{Genus Chlamydophorella Cookson \& Eisenack 1958}

aff. Chlamydophorella nyei (Cookson \& Eisenack 1958)

Plate 1, figs 1-8; Plate 2, figs 1-5; text fig. 4.

Remarks: The present species occurs in one sample from the Jydegård Formation and may therefore be restricted to a very short interval close to the Ryazanian-Valanginian boundary. However, if the species is a morphological variation of $C$. nyei as is indicated by some specimens, then the stratigraphical value is strongly diminished. $C$. nyei has a broad range from Late Jurassic to Late Cretaceous.

Description: The cysts are cavate to proximate. They are pear-shaped in equatorial view with a subspherical to ovoidal main body which merges into a broad and short apical horn. When cavate, the shape of the endocyst is identical to the pericyst.

The archaeopyle is apical of type $\overline{\mathrm{tA}}$. A single operculum is detached. Short, accessory breakages in the archaeopyle margin indicate the parasutures between the precingular paraplates.

The wall of these cysts is two-layered. An autophragm forms an internal capsule separated by short, massive and slender processes from an external capsule of the ectophragm. The autophragm is densely micro-granular and approximately $1 \mu \mathrm{m}$ thick. The ectophragm is smooth and less than $1 \mu \mathrm{m}$ thick. Pores in the ectophragm of varying shape and size may be of secondary origin or may be the initial part of the general decomposition of this layer. The arrangement of the processes appears to be haphazard. However, on several specimens the processes show an intratabular arrangement leaving pandasutural zones. Some SEM-photos show parasutures on the surfaces of the ectophragm as low and narrow trenches. These have not been recognised during light-microscope work.

The wall structure of these cysts is complex as several morphological features vary significantly (Pl. 2, figs 1-5). At one end of the variation spectrum there are holocavate cysts with an autophragm well separated from an ectophragm by slender processes. Reduction in length of the processes juxtaposes the two wall layers. The apical and partly the antapical region remain cavate but the ectophragm in these regions is often decomposed.

The processes between the two wall layers form coarse bulges on the surface of the cysts superficially similar to very coarse granules (Plate 2 , figs 4-5). By reduction of the ectophragm the only remains are confined to small draping fragments over individual processes (fig. 4). The micro-granular autophragm then forms the surface of the cysts. The other end of the variation spectrum thus basically comprises proximate, coarsely granular cysts with one wall layer (Plate 2, fig. 1). Several of these steps of variation may be found within one specimen.

The paratabulation is vaguely indicated. The position and shape of the archaeopyle and the accessory sutures indicate the apical and precingular paraplate series. Pandasutural zones occur within the wall of some cavate specimens. Parasutures have been recognised at very high magnification (SEM) on the surface of a few specimens, but have not been compiled into a tabulation pattern. Together, these features indicate a gonyaulacoid tabulation pattern.

The paracingulum is inconsistently indicated as a process-free zone. The parasulcus is not indicated.

Discussion: The gross morphology of this species is similar to the monotypic genus Jansonia Pocock 1972 of the Middle Jurassic. However, the morphological variations of the cyst.walls suggest affinity to the genus Chlamydophorella, especially the typespecies $C$. nyei. The morphological differences between the present specimens and true $C$. nyei may reflect environmental stress such as low salinity. The majority of specimens deviate in morphology from $C$. nyei but a few specimens have a morphology approaching the definition of $C$. nyei.

The cysts are smaller than the type material but the largest specimens fall within the lowest part 
of the the $C$. nyei size-range. The smaller size is partly explained by the reduced length of processes.

Dimensions: 10 specimens with the operculum in situ have been measured. The length varies from 32 to $46 \mu \mathrm{m}$, average $37 \mu \mathrm{m}$. The width varies from 22 to $36 \mu \mathrm{m}$, average $30 \mu \mathrm{m}$. The maximum length of the processes is approximately $3 \mu \mathrm{m}$, but the average is $1 \mu \mathrm{m}$ or less.

Genus Cleistosphaeridium Davey, Downie, Sarjeant \& Williams, 1966

Remarks: 3 species of Cleistosphaeridium-like cysts are recorded in the upper part of the formation (fig. 7), but have not been worked out morphologically. They have not been identified as knwon species and are therefore treated informally. The three species are mainly separated on the basis of differences in morphology of their processes.

Cleistosphaeridium sp. 1 has simple, tappering acuminate processes.

Cleistosphaeridium sp. 2 has similar processes distally extended into a whiplash. Cleistosphaeridium $\mathrm{sp}$. 3 has cylindrical to tapering processes which are abruptly cut off distally.

Genus Lagenorhytis (Duxbury) Duxbury 1979b emend.

Remarks: The original brief diagnosis of the monotypic genus Lagenorhytis is based on three morphological characteristics: a strong apical horn, a $2 \mathrm{P}$ archaeopyle and no paratabulation. Together with typical Lagenorhytis cysts in marine assemblages (e.g. from the central North Sea, Pl. 3, figs 8-9) a few specimens with reduced apical horns occur. In the upper part of the Jydegård Formation typical Lagenorhytis are absent, but specimens with reduced apical horn occur frequently. As some intermediate forms with reduced apical horn do occur, the specimens without a proper horn are regarded as morphological variations of the type species $L$. delicatula. The diagnosis of genus and species is therefore emended.

Emended diagnosis: Proximate, spheroidal to ovoidal dinoflagellate cysts with a two-plate precingular archaeopyle, presumably $3^{\prime \prime}$ and 4 ". The operculum is compound of two plates, the one $\left(4^{\prime \prime}\right)$ often remaining attached. No cingulum, sulcus or tabulation are reflected by the morphology apart from the shape of the archaeopyle. The cyst wall is single layered (autophragm) and unstructured. If present, surface sculpture is low. A hollow apical protuberance or horn may be present.

Type species: Lagenorhytis delicatula (Duxbury) Duxbury 1979, Valanginian, Speeton Clay.

Discussion: The emendation of the genus diagnosis primarily includes specimens without a significant apical horn. The genera GongylodiniumFenton, Neves \& Piel 1980 (Bajocian-Bathonian) and Bitectatodinium Wilson 1973 (Miocene - Recent) have $2 \mathrm{P}$ archaeopyles and are morphologically similar to Lagenorhytis. Chytroeisphaeridia (Sarjeant) Davey 1979 (Middle - Upper Jurassic (Cretaceous?)) is also very closely related to Lagenorhytis but involves only one paraplate $\left(3^{\prime \prime}\right)$ into the archaeopyle formation. The emendation of Lagenorhytis diminish the morphological differences to the three genera mentioned above.

The flap of the distal archaeopyle margin (Pl. 3 , figs 4-7, Pl. 4, fig. 6) may indicate the presence of an intercalary paraplate or plate series.

Lagenorhytis delicatula (Duxbury) Duxbury 1979 emend.

Plate 3, figs 4-9; Plate 4, fig. 6.

1977 Speetonia delicatula Duxbury p. 49, text fig. 18, Pl. 12, figs 1, 2, $4 \& 5$.

1979 Lagenorhytis delicatula Duxbury, p. 587.

1982 Lagenorhytis delicatula Duxbury in Birkelund, Clausen, Hansen \& Holm, fig. 26

Emended diagnosis: Thin-walled, proximate cysts of spherical to ovoidal shape. A hollow, apical protuberance or a strong apical horn is typical well developed. The wall is single layered (autophragm) and without internal structures. The surface is smooth to finely to coarsely granular. Small tubercles may occur scattered on the surface. Granules or tubercles may be concentrated at the apex. The compound archaeopyle is of type $2 \mathrm{P}$, probably equivalent to paraplates $3^{\prime \prime}$ and $4^{\prime \prime}$. One plate is detached $\left(3^{\prime \prime}\right)$, the other $\left(4^{\prime \prime}\right)$ generally attached. No cingulum, sulcus or 


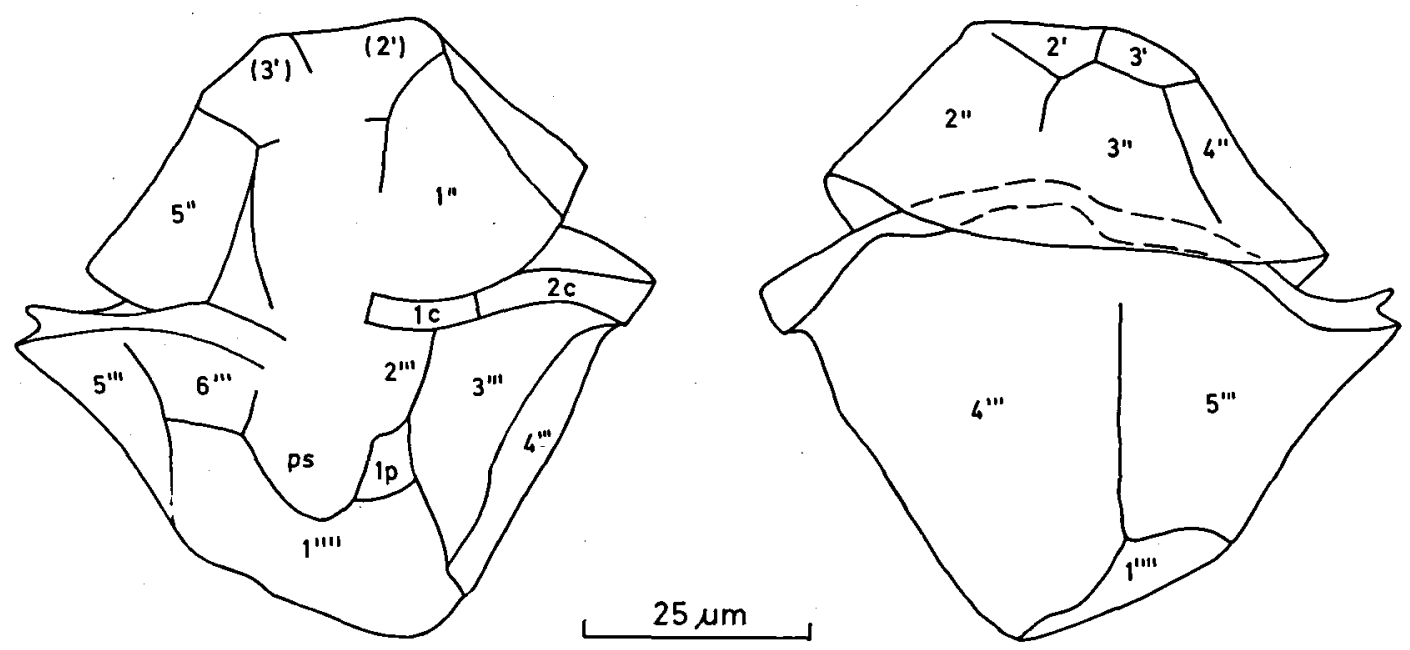

Fig. 5. Camera lucida drawing of the holotype of Mendicodinium rugarum sp. nov. with interpretation of the paratabulation pattern.

paratabulation is reflected by the morphology except for the shape of the archaeopyle.

Holotype: Pl. 12, fig. 4, Duxbury 1977. Paratypes: Pl. 12, figs 1, 2 and 5, Duxbury 1977.

Dimensions: Duxbury (1977) measured 19 specimens: the length varied from 75 to $118 \mu \mathrm{m}$, average $95 \mu \mathrm{m}$, and the width varied from 61 to 103 $\mu \mathrm{m}$, average $82 \mu \mathrm{m}$. 29 specimens were measured in the Jydegård Formation. The length of the cysts varies from $65 \mu \mathrm{m}$ to $92 \mu \mathrm{m}$, average $78 \mu \mathrm{m}$. The width varies from $58 \mu \mathrm{m}$ to $83 \mu \mathrm{m}$, average 68 $\mu \mathrm{m}$.

Mendicodinium Morgenroth, 1970.

Medicodinium rugarum sp. nov.

Plate 4, figs $1-5,7,8$; text fig. 5 .

Diagnosis: Proximate dinoflagellate cysts with a rounded biconical to polygonal shape in equatorial view. The cyst wall is thin and composed of one layer. The surface is apparently smooth, but a longitudinal striation may be present. SEManalysis shows that the surface is finely sculptured (micro-rugulate). No internal wall structures are present. Paracingulum is well indicated by upfolded or thickened parasutures. In general, the paratabulation is vague but indicates a gonyaulacoid tabulation pattern: ?4', $6^{\prime \prime}, ? \mathrm{c}, 5^{\prime \prime \prime}$, 1p, $1^{\prime \prime \prime \prime)}$. The epicyst is smaller than the hypocyst and the archaeopyle is formed by detachment of the epicyst; type $\overline{\mathrm{tAtPa}}$.

Derivation of name: From the latin word rugare: to crease.

Description: The shape of the cysts is rounded biconical to polygonal. The paracingulum marks the equatorial line and the epicyst is smaller than the hypocyst. The majority of the cysts are dorsoventrally compressed by sediment compaction indicating an original slightly dorso-ventral flattening. During diagenesis, the thin wall is liable to strong folding and together with a faint striation of the surface a very wrinkled appearance of the cysts is induced.

The archaeopyle is formed by a suture anterior to the paracingulum. The simple operculum, the epicyst, may be attached to the hypocyst in the sulcal region, but the attachement is often ruptured along an irregular suture. The archaeopyle is of type $\overline{\mathrm{tAtPa}}$.

The wall is composed of one layer, the autophragm, and is very thin, less than $0.5 \mu \mathrm{m}$ thick. Internal structures are absent and the surface appears to be smooth. Surface striation is variably evolved but when present, the striation is mainly longitudinal compared to the polar axis of the cyst. SEM analysis shows that the surface is microsculptured; the sculptural elements are 
smaller than the resolution of a transmission light microscope. The sculpture is micor-rugulate. Variations in the micro-sculpture, alternating smooth ridges and grooves form the coarser faint striation.

The paratabulation is very incompletely reflected by low folds or thickenings of the wall and the pattern is further obscured by frequent compressional folds; the paracingulum and the parasutures of the dorsal region are best indicated. The paratabulation is interpreted as a gonyaulacoid type, the paratabulation formula being $74^{\prime}, 1-6^{\prime \prime}$, ?c, 2-6"' , 1p, $1^{\prime \prime \prime \prime}$. The holotype illustrates the most complete paratabulation recorded in this material.

Discussion: The genus Mendicodinium was defined by Morgenroth to include proximate, nontabulate species with indications of paracingulum - parasulcus and possessing an epicystal archaeopyle. Mendicodinium rugarum sp. nov. deviates from the type species mainly in the surface sculpture and the presence of a weak paratabulation. $M$. groenlandicum (Pocock \& Sarjeant) Davey, 1979 and the probably synonymous $M$. woodhamensis Drugg, 1978 reflect no tabulation at all.

Dimensions: 9 complete specimens were measured. The length of the cysts varies from 59 to 80 $\mu \mathrm{m}$, average $67 \mu \mathrm{m}$. The width of the cysts varies from 60 to $74 \mu \mathrm{m}$, average $66 \mu \mathrm{m}$. Holotype: Pl. 4, fig 1 , length $74 \mu \mathrm{m}$, width $64 \mu \mathrm{m}$. Paratype: PI. 4, fig 2 , length $80 \mu \mathrm{m}$, width $74 \mu \mathrm{m}$. Paratype: Pl. 4 , fig 3, length $65 \mu \mathrm{m}$, width $68 \mu \mathrm{m}$.

Genus Sentusidinium Sarjeant \& Stover, 1978.

Sentusidinium pelionense Fensome, 1979. Plate 3, figs 1-3.

1979 Sentusidinium pelionense Fensome, p. 13-15, text fig. 5B, Pl. 1, figs 5-9.

Remarks: Sentusidinium pelionense was originally reported from Late Bajocian-Bathonian and Kimmeridgian-Portlandian sediments of East Greenland (Fensome 1979). It was suspected that the Upper Jurassic occurrences were due to reworking.

The material from the Jydegård Formation is compared with the type material from East
Greenland, both populations agreeing in all morphological details. The number of specimens and the facies dependent occurence in the Jydegard Formation exclude the possibility of reworking (Piasecki in prep.). Therefore, the range of the species is extended from Late Bajocian to Ryazanian, possibly Early Valanginian.

The distribution of $S$. pelionense appears to be strongly environmental dependent and this may explain the scattered occurrence. The species does not have a distinctive morphology which may explain the restricted number of published reports of its occurrence.

Genus Subtilisphaera (Jain \& Millepied) Lentin \& Williams, 1976

\section{Subtilisphaera sp.}

Pl. 1, figs. 14.

Remarks: These cysts are morphologically similar to the genus Subtilisphaera especially to the type species, $S$. senegalensis. The morphology has not been worked out in details and the species is therefore treated informally. The cysts are peridinoid in outline and wall cavities are restricted to the small apical horn and, if present, to the antapical horn. Paratabulation is only indicated by the paracingulum. Specimens with vague structures indicating an intercalary archaeopyle type have been found together with specimens apparently with a compound archaeopyle formed by a transapical suture.

The genus is reported to occur earliest in Hauterivian (Duxbury 1977, Davey 1979).

\section{Other Algae}

Besides the dinoflagellate cysts in the Jydegård Formation, which are listed in the range-chart (fig. 7), a number of other algal genera have been recorded: Botryococcus, Schizosporis, Schizophacus, Schizocystia, Spirogyra, Peltacystia, Pterospermella, Tasmanites, Leiosphaeridia, Cyclopsiella, Veryhacium and Michrystridium. Botryococcus and Schizosporis occur frequently throughout the formation in contrast to the remainder which occur rarely and inconsistently. 


\section{Dinoflagellate cyst stratigraphy}

The abundance and diversity of stratigraphically diagnostic dinoflagellate cysts in the Jydegård Formation is low. In contrast, long-ranging, less diagnostic species are very abundant and totally dominate the assemblages throughout most of the formation. This appears to be the case in many of the limnic-brackish sediments of Late Jurassic - Early Cretaceous age in northern Europe. Palynological studies of these sediments mainly concern pollen and spores, and the dinoflagellate cysts and other algal palynomorphs are treated as an insignificant supplement to the pollen and spores assemblages. Norris $(1965,1969)$ and Dörhöfer \& Norris (1977) include the dinoflagellate cysts in their stratigraphical work on these sediments.

On the other hand, the highly diverse marine dinoflagellate cyst assemblages of NW Europe and the North Sea region have been subject to far more detailed studies (Gocht 1957, 1959, Klement 1960, Alberti 1961, Duxbury 1978, 1979a, 1979b, Davey 1974, 1979, 1982, Fisher \& Riley 1980, Woollam \& Riding 1983) and a dinoflagellate cyst stratigraphy has been established across the Jurassic - Cretaceous boundary (Davey 1979, 1982). The majority of the species known from marine assemblages do not occur in the Jydegård Formation, but some of the stratigraphically important species appear to have a wide environmental tolerance from brackish to open marine waters, and from near-coastal and lagoonal environments across the shelf. The biostratigraphical work of Davey $(1979,1982)$ on the Bream Formation (Deegan \& Schull 1977) of the Haldager no. 1 borehole in Jylland (fig. 1) is excellent for stratigraphical comparison with the Jydegård Formation. The Late Jurassic - Early Cretaceous Bream Formation in the Danish-Polish Basin is marine in contrast to the Early Cretaceous sediments of the Nyker Group on Bornholm which are fluviatile, littoral and lagoonal marine, brackish and fluviatile (Surlyk 1980, Gravesen, 1982). The Haldager borehole is the nearest locality to Bornholm where a modern dinoflagellate stratigraphy of Lower Cretaceous sediments has been established.

\section{Biozonation}

The Jydegård Formation can be subdivided into two biostratigraphical units on the basis of dinoflagellate cysts (fig. 6). The lower unit belongs to the Gochteodinia villosa Zone (Davey 1979) and the upper unit belongs to the Pseudoceratium pelliferum Zone (Davey 1979). The boundary between the zones is defined by the first occurrence of Pseudoceratium pelliferum Gocht 1957 which occurs earliest at 76 metres in DGU 244165 (figs $6 \& 7$ ). The lower boundary of the G. villosa Zone and the upper boundary of the $P$. pelliferum Zone are not identifiable in the Jydegård Formation. The $G$. villosa Zone interval of the sequence belongs to the Scriniodinium pharo Subzone (Davey, 1979) defined as the interval from the extinction of Cannoshaeropsis thula Davey, 1982 to the first occurrence of $P$. pelliferum. This is strongly supported by the recorded assemblage from this part of the Jydegård Formation as discussed later. It has not been possible to subdivide the sequence of the $P$. pelliferum Zone into Subzone $\mathbf{a}$ and $\mathbf{b}$ of Wollam \& Riding (1983) as the relevant species were not recorded. On the basis of the assemblage in this part of the sequence most of the $P$. pelliferum Zone is regarded as present.

\section{Age of Jydegård Formation}

The G. villosa and $P$. pelliferum Zones are equivalent to a time interval from Middle Volgian to Early Valanginian, but the following discussion indicates that the Jydegård Formation is equivalent to the latest part of this interval only, i.e. Late Ryazanian to Early Valanginian.

\section{Stratigraphical discussion}

Gochteodinia villosa Zone: Sentusidinium pelionense Fensome 1979 is the dominant species in the lower part of the sequence, but is not yet stratigraphically significant as the only previous report indicates a range from Middle to Late Jurassic in sediments from East Greenland (Fensome 1979). The occurrence in the Jydegård Formation extends this range upwards into the Lower Cretaceous. 


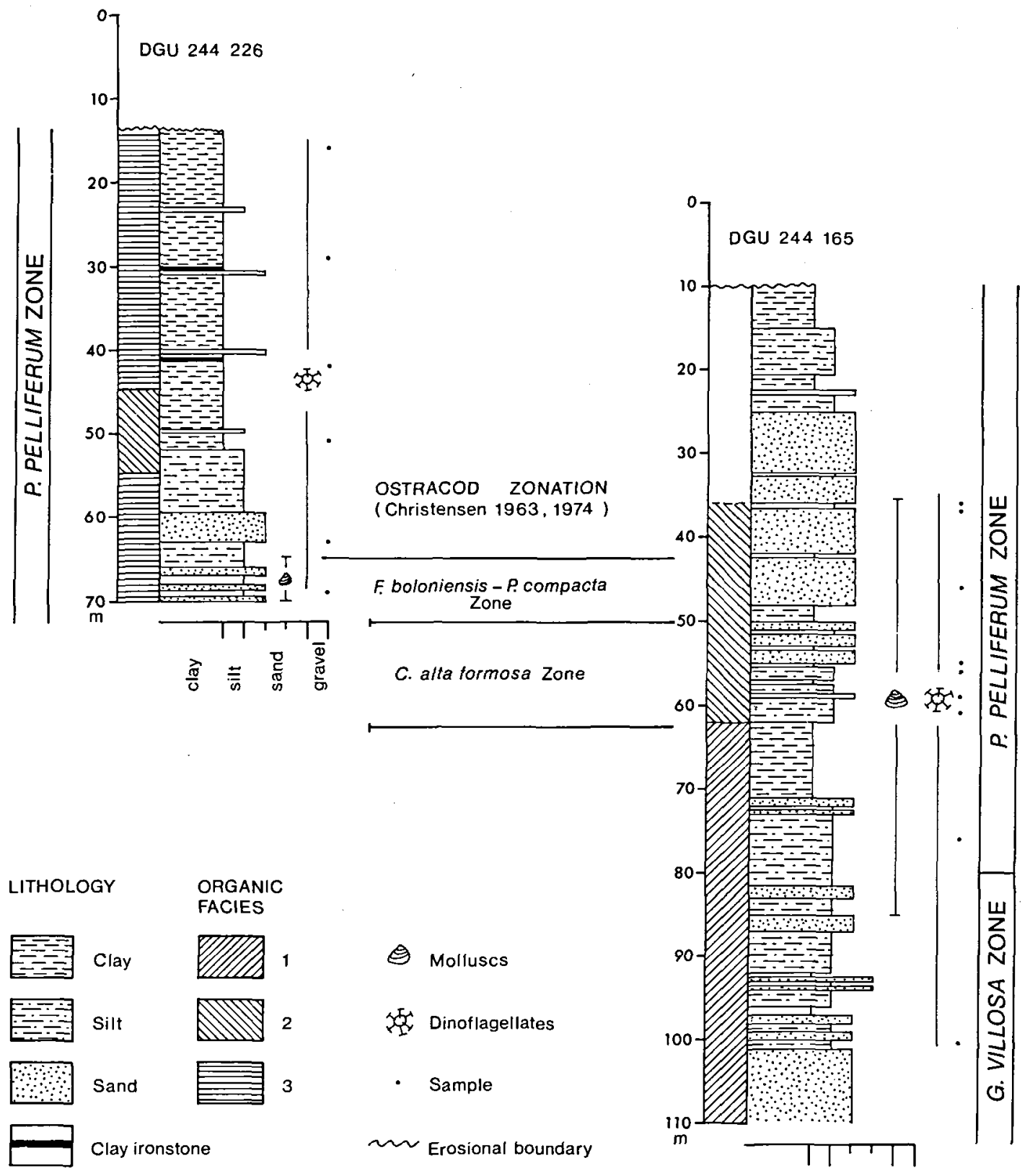

Fig. 6. Sedimentological logs of the Jydegard Formation, Rødbjerg Member in the two boreholes DGU 244165 and 244226 . The logs are simplified after detailed core-descriptions by P. Gravesen, DGU. The biostratigraphical zonations and correlations are indicated together with the palynofacies distribution through the sequences (Piasecki in prep.).

The freshwater alga Schizosporis reticulatus (Cookson \& Dettmann) Pierce 1974 is reported to have its first occurrence in the Berriasian (Singh 1971, Norris 1969). It occurs earliest first in the basal Ryazanian of southern England (suite C of Norris 1969) and in NW Germany (Hils 1-2 of Dörhöfer 1977). The occurrence of
$S$. reticulatus in all samples from the Jydegård Formation therefore suggests that the formation is of Ryazanian or possibly younger age.

The presence of Kleithriasphaeridium porosispinum Davey 1982, Batioladinium pomum Davey 1982 and G. villosa villosa (Vozzhennikova) Norris 1978 in the lowermost part of the 
JYDEGARD FORMATION

DINOFLAGELLATE CYSTS

Batioladinium micropodum

Tubotuberella sp.

Prolixosphaeridium sp.

Muderongia simplex subsp. microperforata

Isthmocystis distincta

Eatioladinium pomum

Gochteodinia villosa

Kleithriasphaeridium porosispinum

sentusidinium pelionense

Muderongia simplex

Cantulodinium speciosa

Mendicodinium rugarum sp.nov.

Imbatodinium pelliferum

Systematophora aff. areolata

subtilisphaera sp.

Cribroperidinium granulatum

Canningia compta

Ctenidodinium aff, panneum

Heslertonia pellucida

Cyclonephelium distinctum

Systematophora sp.

Hystrichodinium voigtii

Gonyaulacysta helicoidea

systematophora spp.

Pseudoceratium pelliferum

Kleithriasphaeridium eoinodes

KIeithriasphaeridium fasciatum

Cleistosphaeridium sp. 1

Lagenorhytis delicatula emend.

Dingodinium albertii

Meiourogonyaulax pertusa

Cleistosphaeridium sp. 3

aff. Chlamydophorella nyei

Pareodinia ceratophora

cleistosphaeridium sp. 2

aft. Callaiosphaeridium sp.

cribroperidinium sp.
DGU244165 DGU 244226

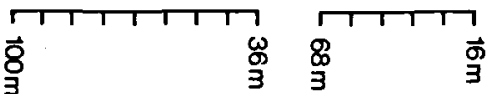

-

-

$\bullet$

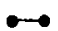

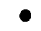

$\bullet$

$\bullet$

-
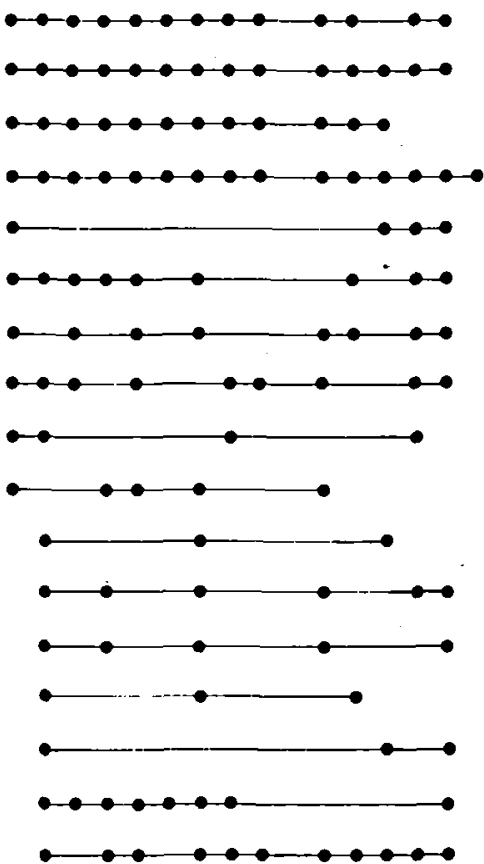

-

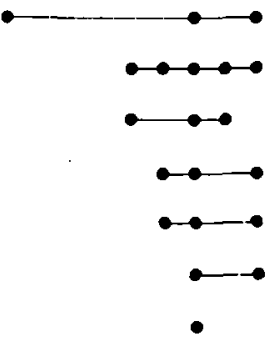


sequence only, indicates an age no younger than Ryazanian for this part of the sequence. This age is further restricted to Late Ryazanian by the presence of Muderongia simplex Alberti, 1961 and Cantulodinium speciosum Alberti, 1961.

C. speciosum is only reported from a very restricted geographical region. Alberti (1961) found the species in Valanginian to Hauterivian sediments from middle and northern Germany (Berlin and Mecklenburg areas). Evitt in Stover \& Evitt (1978) reports one specimen from subsurface sediments of Denmark which now are known (Evitt pers.comm. 1981) to correspond to the same core from the Haldager 1 borehole from which Davey (1982) reports the first occurrence of the species. A Jurassic occurrence for this species can therefore be excluded.

Davey found at few specimens at two levels in the Haldager 1 borehole. The lowest level corresponds to the uppermost part of the G. villosa Zone, Late Ryazanian, and the upper level is in Hauterivian sediments, which partly confirms the observations of Alberti (1961). The occurrence of C. speciosum throughout the Jydegård Formation therefore indicates that the formation is no older than Late Ryazanian. None of the occurring dinoflagellate cysts contradict this.

The first occurrence of $P$. pelliferum at 76 metres in DGU 244165 (fig. 7) is coincident with the last occurrence of $G$. villosa villosa. This could indicate that $G$. villosa villosa is reworked into these sediments or that the record of one $P$. pelliferum specimen that early in the sequence is due to contamination. On the other hand, the dinoflagellate cyst assemblage from that specific sample includes a number of species which have a first or last occurrence very close to the first occurrence of $P$. pelliferum in the Haldager no. 1 borehole (Davey, 1982): i.e. Heslertonia pellucida Gitmez, 1970, Muderongia simplex microperforata Davey, 1982, B. pomum, and K. porosispinum. Therefore it is concluded that this is the actual first occurrence of $P$. pelliferum (the lower boundary of the $P$. pelliferum Zone) and that $G$. villosa villosa and $P$. pelliferum do have a short common occurrence.

Pseudoceratium pelliferum Zone: The zone comprises the main part of the Jydegard Forma- tion in DGU 244165 from 76 metres upwards as well as all the sediments in DGU 244226 (figs 6 \& 7). In the Speeton Clay sequence in England the $P$. pelliferum Zone is equivalent to the $P$. albidium and the lower part of Paratollia sp. ammonite Zones (Casey 1963) of the uppermost Ryazanian and lowermost Valanginian. This part of the Jydegard Formation is therefore of Late Ryazanian to Early Valanginian age.

A number of species are reported to have a first occurrence simultaneously with the first occurrence of $P$. pelliferum (see Duxbury 1977, Davey 1979, 1982). Kleithriasphaeridium fasciatum (Davey \& Williams) Davey 1974 and Meiourogonyaulax pertusa Duxbury 1977 appear higher in the Jydegård Formation and support this identification of the $P$. pelliferum Zone. Lagenorhytis delicatula (Duxbury) emend. is reported to have its first occurrence at the Ryazanian - Valanginian boundary (Duxbury 1977, Davey 1982) and its occurrence in the Jydegård Formation may indicate this boundary as well.

No significant datum levels were recorded in the upper part of the formation though a fairly marine assemblage was recorded. It is significant that the genera Spiniferites and Phoberocysta do not appear even though both genera are common in marginal marine environments. In the Haldager no. 1 borehole both these genera occur for the first time in the Valanginian (Davey, 1982) and this appearance is delayed when compared to the North Sea region (Davey 1979, Duxburry 1977, Fisher \& Riley 1980; Riding \& Wollam 1983, Birkelund et al. 1983. On the basis of the non-appearance of Phoberocysta and Spiniferites the uppermost part of the Jydegård Formation is considered to be of Early Valanginian age. The scattered occurrence of Caningia compta Davey 1982 supports this dating, but otherwise the assemblage is composed of longranging or non-diagnostic species.

\section{Biostratigraphical correlation of the Tornh $\varnothing j$ and the Rødbjerg Members}

The lateral changes of the dinoflagellate cyst assemblages in the Jydegård Formation are sub-

Fig. 7. Distribution of dinoflagellate cysts in the Jydegård Formation from the boreholes DGU 244165 and 244226. 
stantial and probably reflect a rapidly changing palaeoenvironment, in particular with regards to salinity fluctuations. The zonation and dating of the formation are mainly based on a study of the fine-grained Rødbjerg Member. A detailed biostratigraphical correlation between the Rødbjerg Member and the coarse-grained Tornhøj Member is not possible as the stratigraphically important species are absent in the latter member and only two species occur in the fine-grained beds of the Tornhøj Member. The one bed which is an exception is discussed below. $S$. pelionense is highly abundant at some levels in the Tornh $\varnothing j$ Member (Piasecki in prep.) and indicates a lateral equivalence to the lower part of the Rødbjerg Member, where this species dominates the dinoflagellate cyst assemblage (more than 90\%) in contrast to its declining abundance upwards. Similarly the second species of the $S$. pelionense assemblage from the Tornh $\varnothing \mathbf{j}$ Member, $C$. speciosum, attains maximum density in the lower part of the Rødbjerg Member, though it is never abundant.

The assemblage in the uppermost sample of the Tornhøj Member which contains dinoflagellate cysts, deviates substantially from the assemblages below. It is dominated by Cyclopsiella sp., but Ctenidodinium aff. cumulum and Systematophora-type cysts are abundant. S. pelionense and $C$. speciosa are absent. This assemblage can be correlated with the assemblage at 61 metres in DGU 244165 in the Rødbjerg Member as Cyclopsiella sp. and the Systematophora-types become abundant from this level and continue upwards. Dinoflagellate cysts are absent higher in the Tornh $ø j$ Member. This is in accordance with the fluviatile interpretation of this unit (Noe-Nygaard \& Surlyk in prep).

\section{Correlation with ostracod stratigraphy}

Christensen (1963) examined the content of calcareous microfossils in the Jydegård Formation and established two ostracod biozones which were subsequently correlated with zonations in northern Germany (Christensen 1974). They are considered of Late Purbeckian and Wealdian ages. The later work of Dörhöfer \& Norris (1977) on spores and pollen permits a more detailed dating of these ostracod zones. The Cypridea alta formosa Zone and the overlying Fabanella boloniensis - Pachycytheridia compacta Zone of Christensen (1963) were considered equivalent to the middle of the Wealden 3 unit (Wolburg 1959) and to the upper part of Wealden 3 and Wealden 4 units respectively. Dörhöfer \& Norris (1977) correlate these units on the basis of pollen and spores with the latest Ryazanian and earliest Valanginian and place the Ryazanian - Valanginian boundary in Wealden 4 . The dating of the Jydegård Formation on the basis of dinoflagellate cysts and ostracods is therefore in full accordance.

Acknowledgements. The author thanks P. Gravesen of the Danish Geological Survey, for making samples and core-descriptions available. J. M. Hurst and F. Surlyk are thanked for discussions and for suggestions to improve the manuscript. $K$. Villadsen prepared the samples, B. Sikker Hansen produced the figures and $\mathrm{N}$. Turner typed the manuscript. The Geological Institute, University of Copenhagen, is thanked for permission to use the scanning electron microscope.

\section{Dansk sammendrag}

Jydegård Formationen på Bornholm kan biostratigrafisk dateres på grundlag af dinoflagellat cyster. Det undersøgte materiale stammer fra to kerneboringer udført af Danmarks Geologiske Undersøgelse. Boringerne er udført i Nyker forkastningsblokken, hvor Jydegård Formationen er repræsenteret ved det finkornede R $\varnothing \mathrm{dbjerg}$ Led, som ikke er blottet på overfladen. Materiale fra Tornhøj Leddet fra daglokaliteter i Robbedale området er også inddraget $\mathbf{i}$ undersøgelsen, men er karakteriseret ved et specielt og begrænset indhold af dinoflagellat cyster. Der er identificeret to dinoflagellat zoner i Jydegård Formationen: Gochteodinia villosa Zonen og Pseudoceratium pelliferum Zonen. Alderen af formationen er seneste Ryazanian til tidligste Valanginian. Dette er i overensstemmelse med en tidligere datering af formationen på grundlag af ostracoder.

Jydegård Formationen er hovedsagelig aflejret $i$ en brakvands lagune og sedimenteme indeholder derfor en del cyster, som ikke normalt rapporteres fra marine sedimenter. Desuden forekommer en del ferskvands alger. En ny art dinofalgellat cyste er beskrevet, Mendicodinium rugarum sp. nov., og diagnosen på den monotypiske slagt Lagenorhytis og på typearten $L$. delicatula er emenderet. Desuden er arterne Cantulodinium speciosum og aff.Chlamydophorella nyei detaljeret beskrevet.

\section{References}

Alberti, G., 1961: Zur Kenntnis mesozoischer und alttertiärer Dinoflagellaten und Hystrichosphaerideen von Nord- und Mitteldeutschland sowie einigen anderen europäischen Gebieten. Palaeontographica, Abt. A, 116, 1-58. 
Birkelund, T., Clausen, C. K., Hansen, H. N. \& Holm, L., 1983: The Hectoceras kochi Zone (Ryazanian) in the North Sea Central Graben and remarks on the Late Cimmerian Unconformity. Danm. geol. Unders., Árbog 1982, 53-72.

Christensen, O. B., 1963: Ostracods from the PurbeckWealden Beds in Bornholm. Danm. geol. Unders., RK. II, $86,56 \mathrm{pp}$.

Christensen, O. B., 1974: Marine Communications through the Danish Embayment during Uppermost Jurassic and Lowermost Cretaceous. Geoscience and Man VI, 99-115.

Cookson, I. C. \& Dettmann, M. E., 1959: On Schizosporis, a new form genus from Australian Cretaceous deposits. Micropaleontology 5, 213-216.

Davey, R. J., 1974: Dinoflagellate cysts from the Barremian of the Speeton Clay, England. Birbal Sahni Inst. of Palaeobotany, Special Publication 3, 41-75.

Davey, R. J., 1979: The stratigraphic distribution of dinocysts in the Portlandian (Latest Jurassic) to Barremian (Early Cretaceous) of northwest Europe. AASP Contributions Ser. 5B, 49-81.

Davey, R. J., 1982: Dinocyst stratigraphy of the latest Jurassic to Early Cretaceous of the Haldager No. 1 borehole, Denmark. Danm. geol. Unders., Ser. B. 6, 57 pp.

Davey, R. J., Downie, C., Sarjeant, W. A. S. \& Williams, G. L., 1966: Studies on Mesozoic and Cainozoic Dinoflagellate Cysts. Bull. Brit. Mus., Nat. Hist.,Supplement 3, 248 pp.

Deegan, C. E. \& Scull, B. J., 1977: A standard lithostratigraphic nomenclature for the Central and Northern North Sea. Inst. Geol. Sciences, Rep. 77/25, 36 pp.

Drugg, W. S., 1978: Some Jurassic dinoflagellate cysts from England, France and Germany. Palaeontographica, Abt. B, 168, 61-79.

Duxbury, S., 1977: A palynostratigraphy of the Berriasian to Barremian of the Speeton Clay, England. Palaeontographica, Abt. B, 160, 17-67.

Duxbury, S., 1979a: Three new genera of dinoflagellate cysts from the Speeton Clay (Early Cretaceous) of Speeton, England. Micropaleontology 25, 198-205.

Duxbury, S., 1979b: On Lagenorhytis Duxbury nom. nov. Taxon 28, p. 587.

Dörhöfer, G., 1977: Palynogie und Stratigraphie der Bückeberg-Formation (Berriasium-Valanginium) in der $\mathrm{Hi}$ Ismulde (NW-Deutschland). Geol. Jb., Reihe A, 42, 3-122.

Dörhöfer, G. \& Norris, G., 1977: Palynostratigraphische Beiträge zur Korrelierung jurassisch-kretazischer Grenzschichten in Deutschland und England. N. Jb. Geol. Paläont. Abh., 153, 1, 50-69.

Evitt, W. R., 1967: Dinoflagellate studies II. The archaeopyle. Stanford. Univ. Pubs., Geol. Sci. 10 (3), 88 pp.

Evitt, W. R., Lentin, J. K., Milliond, M. E., Stover, L. E. \& Williams, G. L., 1977: Can. Geol. Surv., Paper 76-24, 11 pp.

Fensome, R. A., 1979: Dinoflagellate cysts and acritarchs from the Middle and Upper Jurassic of Jameson Land, East Greenland. Bull. Gronlands geol. Unders. 132, 96 pp.

Fisher, M. J. \& Riley, L. A., 1980: The stratigraphic distribution of dinoflagellate cysts at the boreal Jurassic - Cretaceous boundary. IV Int. Palynol. Conf., Lucknow (197677) 2, 313-329.

Gitmez, G. U., 1970: Dinoflagellate cysts and acritarchs from the basal Kimmeridian (Upper Jurassic) of England, Scotland and France. Bull Brit. Mus. Nat. Hist. Geol. 18, 233331.

Gocht, H., 1957: Mikroplankton aus dem nordwestdeutschen Neokom. Teil 1. Paläont. Z. 31, 163-185.

Gocht, H., 1959: Mikroplankton aus dem nordwestdeutschen Neokom. Teil II. Paläont. Z. 33, 50-89.
Gravesen, P., 1982: Lower Cretaceous sedimentation and basin extension on Bornholm, Denmark. Danm. geol. Unders., Arbog 1981, 73-99.

Gravesen, P., Rolle, F. \& Surlyk, F., 1982: Lithostratigraphy and sedimentary evolution of the Triassic, Jurassic and Lower Cretaceous of Bornholm, Denmark. Geol. Surv. Denmark, Ser. B, 7, 51 pp.

Gry H., 1956: Wealden aflejringerne pả Bornholm, deres stratigrafi og tektonik. Medd. Dansk geol. Foren.13, 134-140.

Gry, H., 1960: Geology of Bornholm. Guide to excursions nos. A 45 and C 40. Int. Geol. Congr. XXI, Session Norden 1960.

Gry, H., 1969: Megaspores from the Jurassic of the Island of Bornholm. Medd. Dansk geol. Foren. 19, 69-89.

Klement, K. W., 1960: Dinoflagellaten und Hystrichosphaerideen aus dem unteren und mitleren Malm Südwestdeutschland. Palaeontographica, Abt. A, 114, 1-104.

Lentin, J. K. \& Williams, G. L., 1981: Fossil dinoflagellates: Index to genera and species, 1981 edition. Bedford Institute Oceanography Report: BI-R-81-12, 345 pp.

Morgenroth, P., 1970: Dinoflagellate cysts from the Lias Delta of Lühnde/Germany. N. Jb. Geol. Paläont. Abh. 136, 345359.

Noe-Nygaard, N. \& Surlyk, F., in prep.: Sedimentary facies, fauna and flora of the brackish to limnic Jydegdrd Formation, Lower Cretaceous, Bornholm.

Norris, G., 1965: Archaeopyle structures in Upper Jurassic dinoflagellates from Southern England. N. Z. J. Geol. Geophys. 8, 792-806.

Norris, G., 1969: Miospores from the Purbeck Beds and marine Upper Jurassic of Southern England. Palaeontology 12, 574-620.

Norris, G., 1978: Phylogeny and a revised supra-generic classification for Triassic-Quaternary organic-walled dinoflagellate cysts (Pyrrhophyta). Part II. Families and sub-orders of fossil dinoflagellates. N. Jb. Geol. Paläont. Abh. 156, 1-30.

Piasecki, S, in prep.: Palynological analysis of the organic debris in the Jydegaird Formation, Bornholm, Denmark.

Pierce, S. T., 1976: Morphology of Schizosporites reticulatus Cookson \& Dettman 1959. Geoscience and Man 15, 25-33.

Pocock, S. A. J. \& Sarjeant, W. A. S., 1972: Partitomorphitae, A new subgroup of Triassic and Jurassic Acritarchs. Bull. geol. Soc. Denmark, 21, 346-357.

Sarjeant, W. A. S. \& Stover, L. E., 1978: Cyclonephelium and Tenua: A problem in dinoflagellate Taxonomi. Grana 17, 47-54.

Singh, C., 1971: Lower Cretaceous microfloras of the Peace River Area, Northwestern Alberta, Research Council of Alberta Bulletin 28, 542 pp.

Stover, L. E. \& Evitt, W. R., 1978: Analyses of Pre-Pleistocene Organic-walled Dinoflagellates. Stanford Univ. Pubs., Geol. Sci., 15, 300 pp.

Surlyk, F., 1980: Denmark. In: Geology of the European countries, Denmark, Finland, Iceland, Norway, Sweden, 1-50. Dumod. Published in cooperation with the Comité National Français de Géologie (C.N.F.G.) on the occasion of the 26th. International Geological Congress.

Wolburg, J., 1959: Cyprideen des NW-deutschen Wealden. Senck. leth. 40, 223-315.

Woollam, R. \& Riding, J. B., 1983: Dinoflagellate cyst zonation of the English Jurassic. Rep. Inst. Geol. Sci. 83/2, 41 pp. 

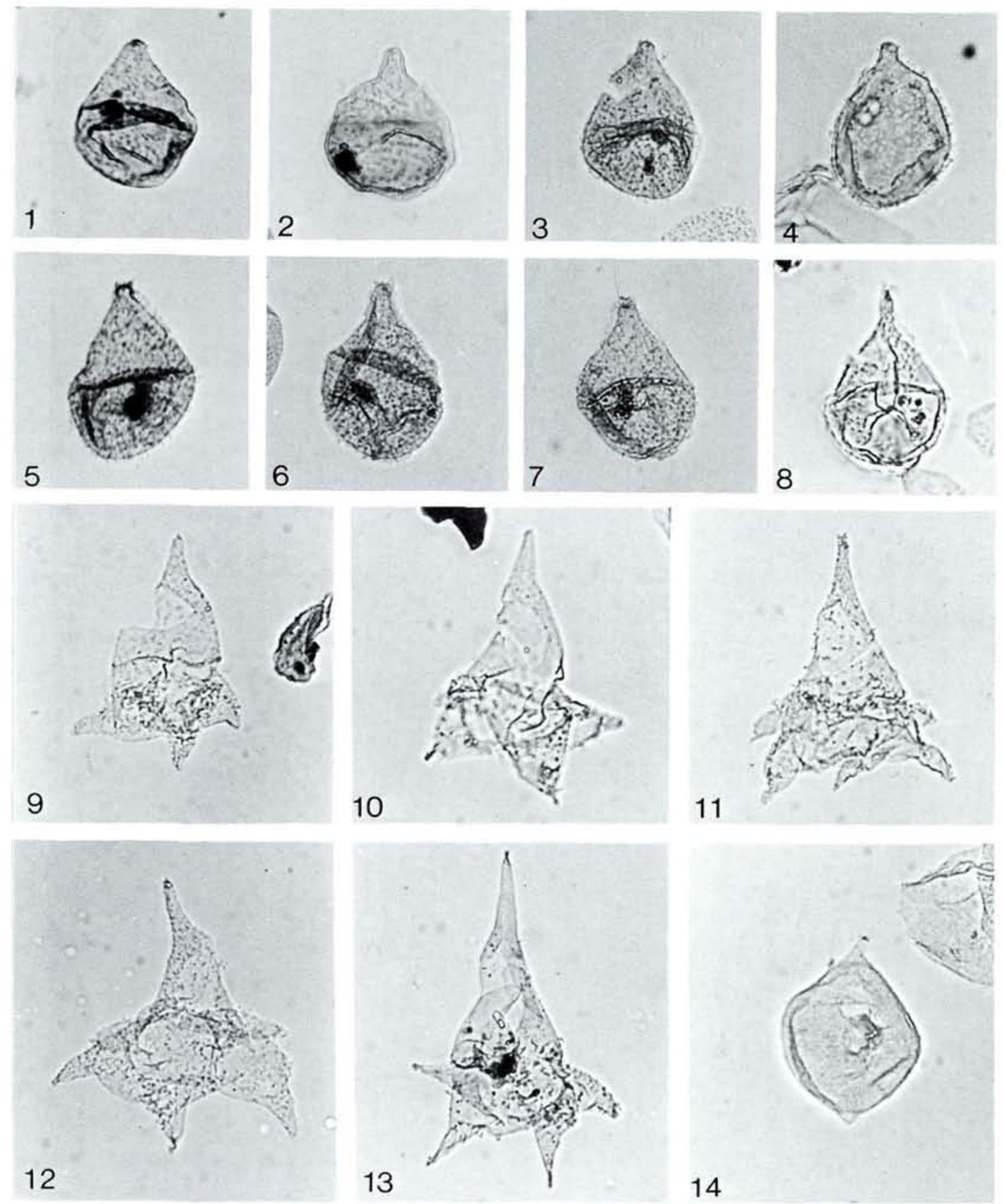

Plate 1. Figs 1-8; aff. Chlamydophorella nyei, MGUH 16237-16244. The series of specimens shows the variation of wall morphology from granular, one-layered specimens (figs 1-2) to spineous specimens (figs 3-4 and specimens with increasing presence of ectophragm and wall cavity especially in the apical region (figs 5-8). The specimen on fig. 8 poses an exceptional thin and long apical horn.

Figs 9-13; Cantulodinium speciosum, MGUH 16245 - 16249. The series of specimens shows the size-variation of the apical and postcingular horns, and the variation in density and distribution of sculptural elements on the surface.

Fig. 14; Subtilisphaera sp., MGUH 16250. All figures approx, $500 \mathrm{X}$.

Plate 2. Figs 1-5; aff. Chlamydophorella nyei. Fig. 1; The archaeopyle margin with the ectophragm reduced to large sculptural elements on the surface of the one-layered wall, autophragm, $12500 \mathrm{X}$. Figs 2-3; Apical regions of specimens with the ectophragm disintegrated exposing the spines which were formerly within the wall cavity, 2500 \& $9000 \mathrm{X}$. Figs $4-5$; Specimens with the ectophragm well preserved and partly exposing a tabulation pattern. The surface of the cysts appears coarsely granular reflecting the spines of the wall cavity, $1750 \& 1500 \mathrm{X}$. 


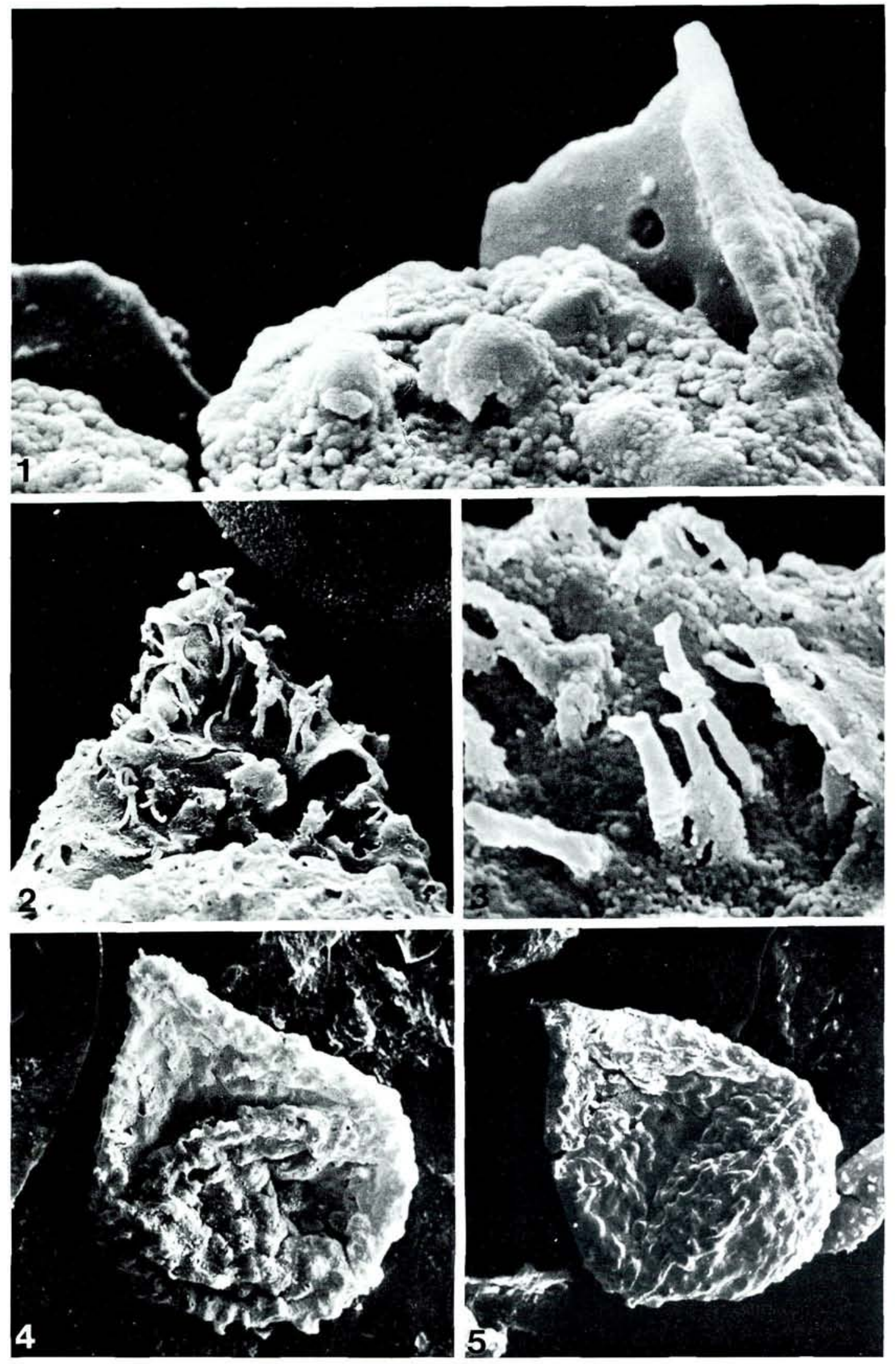



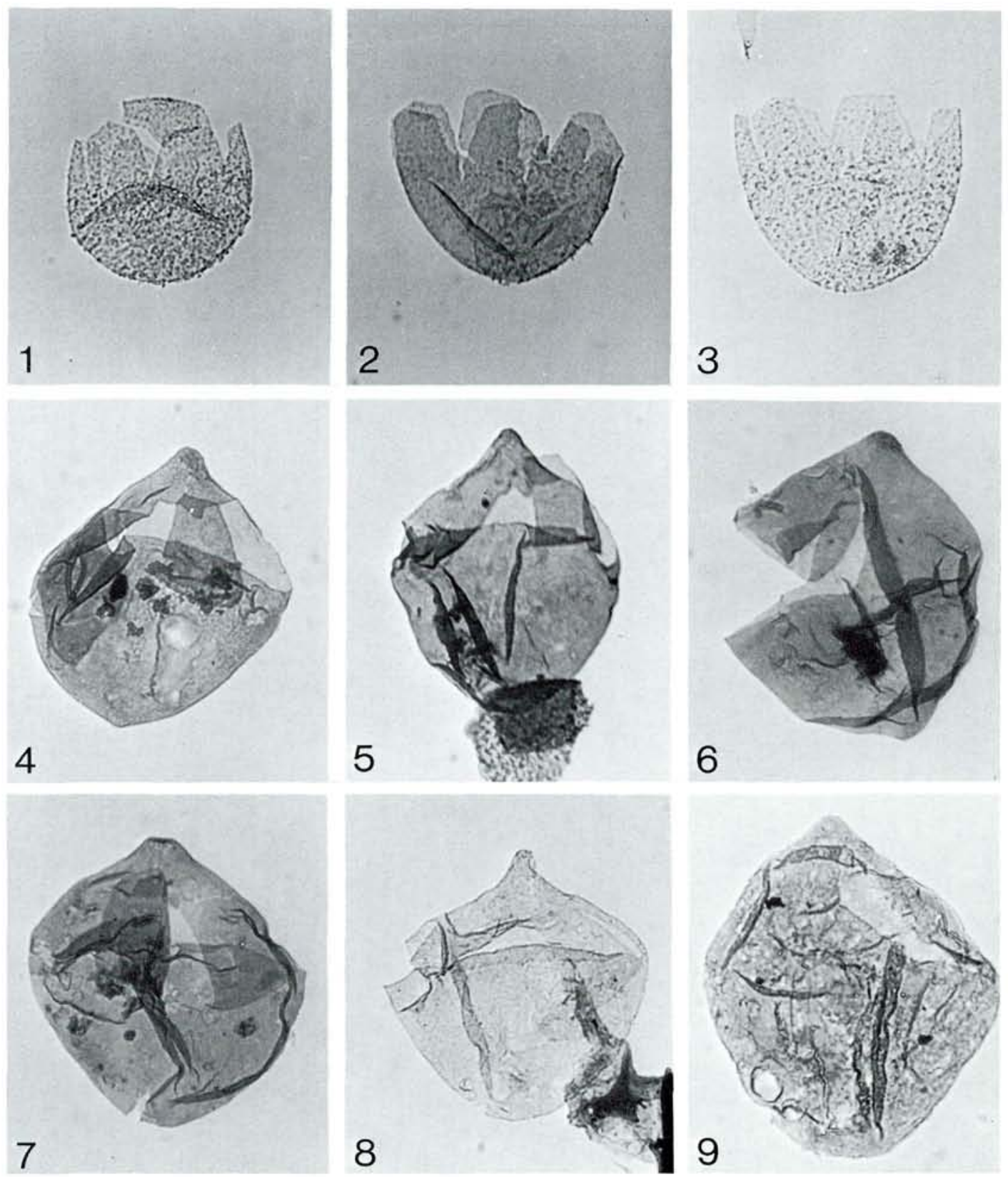

Plate 3. Figs 1-3; Sentusidinium pelionense, MGUH 16251 - 16253. The specimen in fig. 1 has exceptionally the operculum attached. Figs 4-9; Lagenorhytis delicatula emend. Figs 4-7, MGUH $16254-16257$, specimens from the Jydegård Formation showing reduced apical horns. The 4" paraplate of the archaeopyle remains generally attached to the cysts. The specimens in fig. 6 is oriented in lateral view. Figs 8-9; Specimens from the central North Sea (E 1 well, Birkelund et al., 1983) also showing reduced apical horns. Fig. 8, MGUH 16095. Fig. 9, MGUH 16258. All figures approx. $500 \mathrm{X}$. 

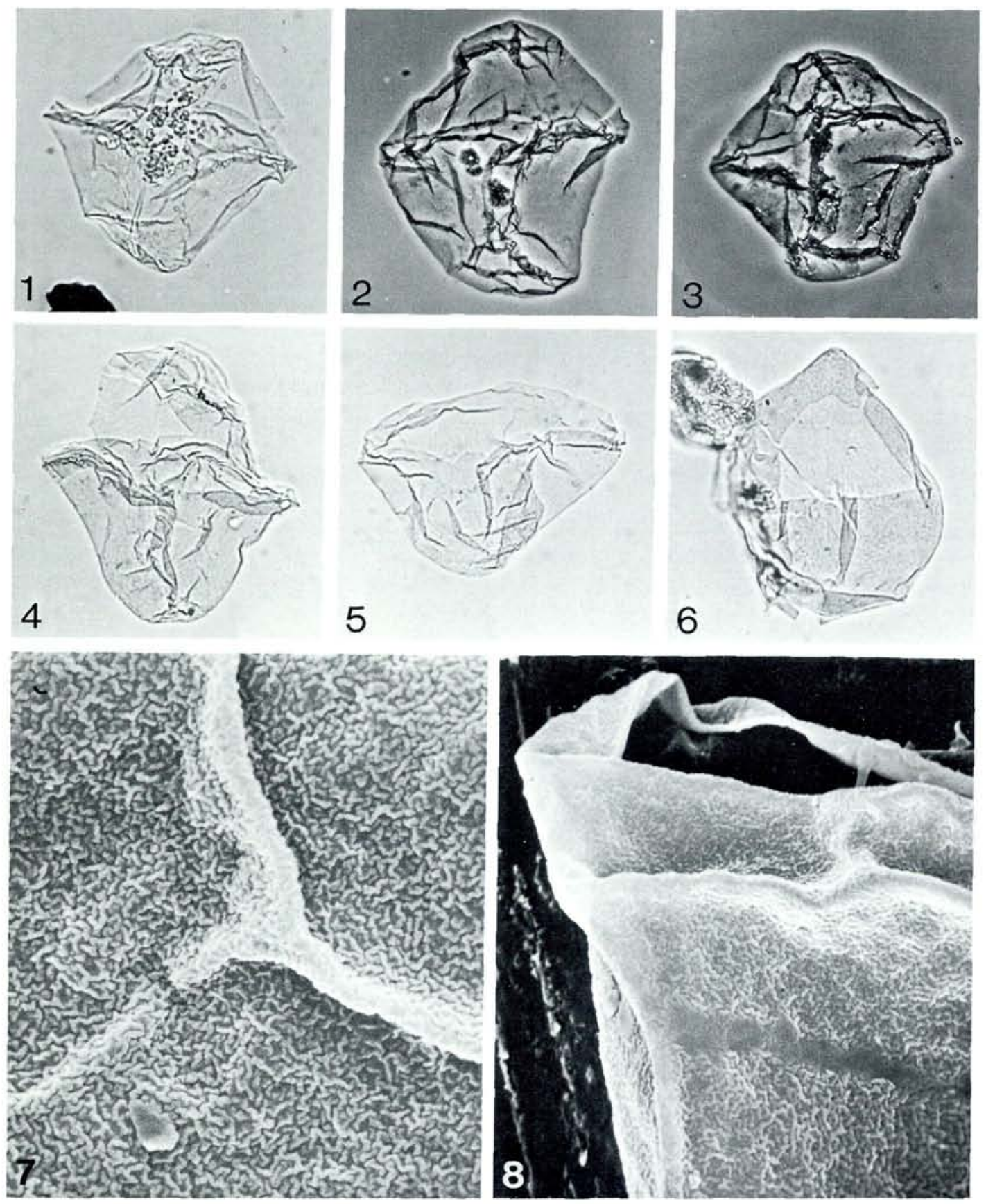

Plate 4. Figs 1-5, 7, 8; Mendicodinium rugarum sp. nov. Fig. 1; Holotype, MGUH 16259. Fig. 2; Paratype, MGUH 16260. Fig. 3; Paratype, MGUH 16261. Figs 4-5; MGUH 16262 \& 16263. Figs 1 and 4 show the archaeopyle formation and fig. 5 shows a hypocyst with the operculum detached. Fig. 7; The micro-vermiculate sculpture of the surface and an upfolded parasuture disappearing towards the left, $4500 \mathrm{X}$. Fig. 8; The micro-sculpture formed into a faint, coarser longitudinal striation $4500 \mathrm{X}$. fig. 6 ; Lagenorhytis delicatula emend., MGUH 16264, showing the shape of the $3^{\prime \prime}$ paraplate. Figs 1-6 approx. $500 \mathrm{X}$. 